\title{
An Empirical Analysis of the Energy-Growth Hypothesis for Nigeria (1991 - 2019)
}

\author{
Isere Victoria Oshuare Merab And Bawa Hassan \\ Department of Humanities \& Social Sciences, School of General Studies, Auchi Polytechnic, Auchi
}

\begin{abstract}
Energy consumption is an important indicator of economic modernization and in general the more developed a nation, the more their level of consumption. Improved productivity can unlock development and this is enhanced by availability and accessibility of electricity supply to the manufacturing and industrial sector. Hence this study analyzes the impact of electricity consumed by only the manufacturing and industrial sector; excluding the consumption for domestic use so as to test the energy-growth hypothesis for Nigeria over the period 1981 to 2019. The study also included the impact of electricity consumption on manufacturing output. The analysis was done using OLS techniques and ECM. The results revealed a positive significant relationship between manufacturing output and electricity consumption as well as an inverse relationship between electricity consumption and economic growth in the long run. Granger causality was also done and a unidirectional causality was found from economic growth to electricity consumption; showing support for the conservation hypothesis of the Energygrowth hypothesis. Unidirectional causality was also found from manufacturing to electricity consumption as well. The study recommends the need to develop huge infrastructure for adequate supply of electricity because as the economy grows the need for electricity consumption will increase.
\end{abstract}

DOI: $10.7176 / \mathrm{JETP} / 11-5-03$

Publication date:October $31^{\text {st }} 2021$

\section{INTRODUCTION}

Availability of infrastructure is paramount for development. Every country desiring development devotes resources to provision of infrastructure like electricity, good roads, water and telecommunication to mention a few. Assess of the people to such infrastructure cannot be compromised else the intention of government is not achieved. More often than not the provision of electricity infrastructure is greeted with great joy and happiness by the people of the receiving community hence countries usually begin developing rural communities with the provision of electricity. Accessibility to electricity supply is one of the main factors that determine the level of industrialization and economic development of a nation. When this is enhanced it no doubt will increase the potentials of economic growth. The availability of energy is very important for modern living. Of more importance however is the accessibility. In the Nigerian economy, one infrastructure that even when available is not fully accessible is electricity. One reason usually given for this is inadequate transmission infrastructure (Ukoima \& Ekwe, 2019 and Akinbola, Zekeri \& Idowu, 2017). In addition to this may be because of the fast rate of population growth; urbanization constantly expanding demand above supply.

The scale of consumption of energy per capita is an important indicator of economic modernization according to Adegbemi, Adegbemi, Olalekan \& Babatunde (2013). They opined that in general countries with higher per capita energy consumption are more developed than those with lower levels of consumption. Electric power is a modern innovation that has eased the pains involved in large scale production; encouraging development. The endogenous growth theory associated economic growth with innovations which are driven by human capital development rather than from exogenous factors like population growth rate (Liberto \& Esteveze, 2020). Optimal and efficient development of nations rests squarely on the shoulders of accessibility to energy (electric power).

Accessibility to electric energy aids the process of attaining and sustaining development (Adeyemi, Opeyemi \& Oluwatomisin, 2016) as energy is a major determinant of sustainable development. When electricity generation is much higher than its supply especially in the face of much higher demand it results in a critical problem. This has been an unfortunate case of the Nigerian nation. Following some challenges identified by Okolobah \& Ismail (2013) which had unpalatable effects on other economic variables like unemployment, manufacturing output and economic growth the government had some power sector reforms which saw to the unbundling of the National Electric Power Authority (NEPA) into generating, transmission and distribution companies. Following the unbundling in 2005, Nigeria has six generating companies (GENCOs), 11 distribution companies (DISCOs) and one transmission company (Awosope, 2014). Has this done any significant good to power supply in Nigeria?

There are various sources of energy which have been analyzed as to their impact on economic growth but the impact of electric energy as consumed only for industrial and commercial purpose has never been analyzed. Domestic consumption is high but relatively unproductive so it is important to disintegrate electricity consumption and analyze the impact of commercial and industrial consumption only. It is against this background that this study desires to reveal the impact of electricity supply on economic growth and manufacturing output in Nigeria. The need to check for structural break is also important due to the unbundling policy of government in 2005. 
Availability of energy - power supply- is a very important factor to a nation desiring economic growth and development. In Nigeria as in many countries, the provision of power was changed from one government corporation to another over a long period of time. When the times of privatization and commercialization came, Nigeria adjusted her power industry policy and privatized power supply. The purpose of this was to improve efficiency. Since 2005, when PHCN was unbundled it is important to assess statistically the relationship between electricity supply and economic growth and manufacturing output. This improvement will be shown via a statistically significant structural break. This has not be analyzed by any previous work. A lot has been done in analyzing the impact of power supply on economic growth but not has disaggregated power supply/consumption by excluding power supply/consumed for domestic use which is actually unproductive in terms of increasing production output. This Study handles this aspect as it gives a better analysis to exclude domestic consumption from total electricity consumed.

This study will help to rethink privatization as regards supply of goods like electricity. The study used electricity supply for commercial and industrial use only and checks for structural break after unbundling PHCN in 2005. This study examined the relationship between electricity supply for industrial and commercial use, economic growth and manufacturing output and covers the period 1991 to 2018. This scope is limited by availability of data on disaggregated electricity consumption for earlier years. Annual data is used. The variables of interest are manufacturing output, economic growth (proxied by GDP minus manufacturing output), unemployment, credit to private sector, foreign direct investment (inflows) and electricity supply for commercial and industrial use.

\section{CONCEPTUAL FRAMEWORK: THE ENERGY-GROWTH HYPOTHESIS}

The first study on energy and economic growth dates back to the 1970s as reported by Behera (2015). The study investigated the causal relationship between Gross National product (GNP) and energy in the United States from 1947 to 1974 and found that increased GNP leads to increased energy consumption in the US. The Energy-growth discuss tends to find the causal relationship between energy consumption and economic growth. Energy plays a major role in the energy-growth hypothesis as it is closely linked to economic growth (Behera, 2015). In traditional growth models, capital, labour and land are treated as primary factors of production where energy is seen as a substitutable capital and therefore given a minor role. In the energy-growth hypothesis, energy is key and could be electricity or oil. Behera (2015) posited that economic growth is highly dependent on energy and also promotes research in energy technology utilization and development. There are four conclusions/variants of the energygrowth hypothesis viz:

a. energy-led hypothesis;

b. conservation hypothesis;

c. feedback hypothesis; and

d. neutrality hypothesis

The energy-led growth hypothesis posits that energy consumption causes economic growth - a unidirectional causality - that is economic growth is dependent on energy consumption. The conservation hypothesis argues that economic growth causes energy consumption - unidirectional also but that energy consumption is dependent on economic growth. The feedback hypothesis presents a bi-directional causal relationship between economic growth and energy consumption. This means that economic growth and energy consumption cause each other. Lastly the neutrality hypothesis opines that there is no causal relationship between economic growth and energy consumption.

The presence of unidirectional causality from energy consumption to economic growth (energy-led hypothesis) signals an energy dependent economy in which case energy conservation policies will have adverse impact on economic growth (Apergis \& Danaletiu, 2012). Conversely a unidirectional causality from economic growth to energy consumption (conservation hypothesis) suggests that energy conservation policies may have little or no impact on economic growth. In the same vein, a bi-directional causality (feedback hypothesis) reflects interdependence of both variables while absence of causality means conservation policies will have no significant impact on economic growth.

The impact of electricity consumption on economic growth has been in the forefront of discussions on the impact of energy consumption. Policy makers and users desire to know to what extent breakthroughs in energy supply technology can impact a nation. Adegbemi et al (2013) in an empirical study on energy consumption and economic growth in Nigeria reported that electricity was found to be statistically significant with a positive impact on economic growth. They evaluated the causal nexus over the period 1975 to 2010 using co-integration and Ordinary Least Squares (OLS) techniques. They reported the lack of consensus on existence and direction of causality between economic growth and energy consumption but concluded that increased energy consumption is a strong determinant of economic growth in Nigeria.

Adeyemi et al (2016) examined the relationship between electricity consumption and economic development in Nigeria by adopting an extended neoclassical model for the period 1970 to 2011 using co-integration analysis and Vector Error Correction (VEC) model. Using GDP per capita as a dependent variable, they ascertained the 
direction of causality as unidirectional without expressly reporting the exact direction of the causality. They found an inverse significant relationship between electricity consumption and economic development while they also reported that there was no long run relationship between electricity consumption and economic development. Ahmed \& Mallo (2015) investigated the impact of electricity supply on Small Scale business in North East Nigeria using primary data obtained by questionnaire administered to 245 small scale businesses. The impact of electricity was reported as negative as the incessant supply had hampered business. This showed that business output/growth can be impacted negatively by electricity supply.

Akiri et al (2015) studied the impact of electricity generation on manufacturing productivity in Nigeria between 1980 and 2012 using OLS. Adopting manufacturing productivity as dependent variable, they reported a positive impact of electricity generation on manufacturing productivity growth. This positivity was however not statistically significant. Bernard (2014) reported a distinct unidirectional causality from electricity consumption to economic growth in Nigeria in both long and short run in his paper titled electricity consumption, inflation and economic growth in Nigeria; using a trivariate VEC model. His results supported the energy (electricity) led growth hypothesis.

Nwankwo \& Njogo (2013) used a multiple regression model to examine the effects of electricity supply on industrial production within the Nigerian economy between 1970 and 2014 . They reported a positive impact of electricity supply on GDP as well as on industrial development. The impact on GDP was significant while that on industrial development was not. George-Anokwuru \& Ekpenyong (2020) investigated electricity consumption and economic growth in Nigeria using Auto-Regressive Distributed Lag model with GDP as dependent variable. They reported a positive and statistically significant relationship between GDP and electricity consumption in both the short and long run. Electricity generation was negative and also statistically significant as well while distribution losses were not significant.

Okorie \& Manu (2016) carried out a study to evaluate causality between electricity consumption and economic growth between 1980 and 2014 in Nigeria using Johansen co-integration and Granger causality. Their study revealed that electricity has similar movement with economic growth. A unidirectional causal relationship was found from electricity consumption to economic growth (energy led growth). Their impulse response function revealed that shocks in electricity consumption led to a fall in real GDP in the first period; hitting its lower point towards the end of the period. Ehimhen (2015) also reported a strong. positive and significant relationship between power sector and the level of economic growth in Nigeria in their study on the state of the Nigerian Power sector and its economic implications for the nation between 1999 and 2011 via ANOVA and regression analysis on SPSS.

Akinbola et al (2017) investigated the link between power supply and business industrial development in Nigeria using the Johansen co-integration technique over the period 1981 to 2010. They also did a VEC model to correct disequilibrium in the long run. They extracted industrial component from real GDP and used it as their dependent variable. From the normalized co integration equation the consumption of electricity had a positive impact on industrial development only in the short run. They also reported a unidirectional causality between electricity consumption and industrial output. Behera (2015) presented a time series analysis to examine the evidence of the energy-led growth hypothesis in India. He confirmed a unidirectional causality from economic growth to energy consumption which goes to support the conservation hypothesis of energy consumption. Oil was the however the source of energy examined. Akinlo (2209) also investigated causality between electricity consumption and economic growth in Nigeria. He reported a unidirectional causality from electricity consumption to real GDP. Babatunde \& Adenikinju (2016) studied the energy-led growth relationship for Nigeria using VAR and the variance decomposition on energy consumption, GDP, level of industrialization and urbanization between 1972 and 2014. They concluded that industrial and urbanization stimulate energy consumption and found no causality between energy consumption and economic growth. Their definition of this energy was however not given.

Apergis \& FoonTang (2013) in their study of the energy-led hypothesis for 85 countries revealed that Granger causality models with three and four variables are more likely to support the energy-led hypothesis compared to models that contain only two variables. In addition, both developed and developing countries are more likely to support the energy-led growth hypothesis compared to the less developed or low income countries. Therefore, causality results are very sensitive to the choice of the model specification along with the stages of economic development.

The literature has multiple evidence of the causal relationship existing between electricity consumption and economic growth. The impact electricity has on manufacturing as well as unemployment is yet little as none could be found. All other studies researched on electricity consumed generally while this work is on electricity consumed for only industrial and commercial purpose as domestic consumption though quite heavy is relatively unproductive. Thus this study focuses on the impact of electricity consumed for industrial and commercial purposes on economic growth, unemployment and manufacturing in Nigeria over the period 1991 and 2018. We will also investigate for structural break at the point of privatization of power supply in Nigeria using chow test. 


\section{METHODOLOGY}

Using the augmented Dickey-Fuller unit root test, the stationarity of each series was determined. Secondly, the variables are tested for co-integration using the Johansen co-integration procedure to determine the long run relationship among the variables of interest. The least square technique was used to estimate a long run and short run model and its long run error correction model to determine the speed of adjustment after a shock. Chow test was also used to check for significance of structural break.

\section{Model specification}

The model for this study is an adaptation of Nwankwo \& Njogo (2013). The functional form of their models were given as

$$
\begin{array}{ll}
I N D U=f(G F C F, P O P, E L E C, I N F) & \ldots 3.1 \mathrm{a} \\
G D P P C=f(G F C F, P O P, E L E C, I N D U) & \ldots 3.1 \mathrm{~b}
\end{array}
$$

Where GDPPC = real GDP per capita; GFCF $=$ Gross fixed capital formation

$\mathrm{POP}=$ Population; ELEC $=$ amount devoted to electricity infrastructure as part of GDP

INDU = amount devoted to industrial production; INF = Inflation

In this study, the functional modification of (3.1a and $\mathrm{b}$ ) are:

Model 1: $\quad M A N=f(C I E, G D P, F D I, C P S, U N E) \quad \ldots 3.2 \mathrm{a}$

Model 2: $\quad G D P=f(C I E, M A N, F D I, C P S, U N E) \quad \ldots 3.2 \mathrm{~b}$

Where GDP $=$ Real Gross domestic product in naira

MAN = Manufacturing output

CIE - Commercial and industrial electricity supply/consumption

In operational form

$\mathrm{CPS}=$ credit to private sector and UNE - Unemployment level

Model 1: MAN $=\beta_{0}+\beta_{1} C I E+\beta_{2} G D P+\beta_{3} F D I+\beta_{4} C P S+\beta_{5} U N E+\mu_{t 1} \quad \ldots . .3 .3 \mathrm{a}$

Model 2: $G D P=\delta_{0}+\delta_{1} C I E+\delta_{2} M A N+\delta_{3} F D I+\delta_{4} C P S+\delta_{5} U N E+\mu_{t 2}$

Taking log transformations become

Model 1: $\operatorname{LnMAN}=\beta_{0}+\beta_{1} \operatorname{LnCIE}+\beta_{2} \operatorname{LnGDP}+\beta_{3} \operatorname{LnFDI}+\beta_{4} \operatorname{LnCPS}+\beta_{5} U N E+\mu_{t 1} \quad \ldots . . .3 .4 \mathrm{a}$

Model 2: $\operatorname{LnGDP}=\delta_{0}+\delta_{1} \operatorname{LnCIE}+\delta_{2} \operatorname{LnMAN}+\delta_{3} \operatorname{LnFDI}+\delta_{4} \operatorname{LnCPS}+\delta_{5} U N E+\mu_{t 2} \quad \ldots .3 \mathrm{~b}$

$\beta_{i}$ 's and $\delta_{i}$ 's are the coefficient to be estimated. $\beta_{1}, \beta_{2}, \beta_{3,} \beta_{4}>0 \beta_{5}<0$. And $\delta_{1}, \delta_{2}, \delta_{3}, \delta_{4}>0, \delta_{5}<0$.

\section{Sources of data}

This study relies completely on secondary data sources obtained from various issues of the Central bank of Nigeria's Statistical Bulletin and the website of the International Energy Agency (IEA). The data used are annual time series data spanning from 1991 to 2018.

\section{VI.PRESENTATION AND DISCUSSION OF RESULTS}

Unit Root Tests Results

Table 1: Augmented Dickey-Fuller Unit root tests

\begin{tabular}{|l|c|c|c|c|c|}
\hline Variables & $\begin{array}{c}\text { ADF computed } \\
\text { value at level }\end{array}$ & $\begin{array}{c}\text { 5\% Critical } \\
\text { value }\end{array}$ & $\begin{array}{c}\text { ADF computed value at } \\
1^{\text {st }} \text { difference }\end{array}$ & $\begin{array}{c}5 \% \text { Critical } \\
\text { value }\end{array}$ & Conclusion \\
\hline LnCIE & -0.360521 & -2.976263 & -5.070325 & -2.981038 & $\mathrm{I}(1)$ \\
LnMAN & 0.110377 & -2.998064 & -4.127664 & $-2.998064-$ & $\mathrm{I}(1)$ \\
LnGDP & -0.705660 & .2 .981038 & -7.020474 & 2.981038 & $\mathrm{I}(1)$ \\
LnFDI & -1.597324 & -2.976263 & -9.057291 & -2.981038 & $\mathrm{I}(1)$ \\
LnCPS & -2.601359 & -2.976263 & -3.594573 & -2.981038 & $\mathrm{I}(1)$ \\
UNE & -0.132555 & -2.976263 & -3.799101 & -2.998064 & $\mathrm{I}(1)$ \\
\hline
\end{tabular}

Source: Authors extraction from Eviews 9 output

The table above shows that all the series are I(1). The null hypothesis of the presence of unit roots is rejected (decision rule being to reject the null hypothesis if the absolute value of the ADF statistic is higher than the corresponding 5\% critical value) and the series are all integrated at first difference. Hence we can do a test for cointegration to determine if a long run relationship exists among the variables. 
Johansen Co-integration test results

Table 2: Summary of Johansen co-integration result

\begin{tabular}{|c|c|c|c|c|c|c|c|}
\hline $\begin{array}{c}\text { Hypothesized no. } \\
\text { of CE(s) }\end{array}$ & $\begin{array}{c}\text { Eigen } \\
\text { value }\end{array}$ & $\begin{array}{c}\text { Trace } \\
\text { statistic }\end{array}$ & $\begin{array}{c}5 \% \text { Critical } \\
\text { value }\end{array}$ & Prob & $\begin{array}{c}\text { Max-Eigen } \\
\text { statistics }\end{array}$ & $\begin{array}{c}5 \% \text { critical } \\
\text { value }\end{array}$ & Prob \\
\hline None & 0.792034 & 128.1836 & 95.75366 & 0.0001 & 42.40029 & 40.07757 & 0.0269 \\
\hline At most $1^{*}$ & 0.691346 & 85.78335 & 69.81889 & 0.0016 & 31.73941 & 33.87687 & 0.0881 \\
\hline At most 2* & 0.529220 & 54.04395 & 47.85613 & 0.0117 & 20.34082 & 27.58434 & 0.3180 \\
\hline At most $3^{*}$ & 0.499415 & 33.70313 & 29.79707 & 0.0169 & 18.68341 & 21.13162 & 0.1064 \\
\hline At most 4 & 0.312920 & 15.01972 & 15.49471 & 0.0589 & 10.13321 & 14.26460 & 0.2033 \\
\hline At most 5* & 0.165549 & 4.886507 & 3.841466 & 0.0271 & 4.886507 & 3.841466 & 0.0271 \\
\hline
\end{tabular}

Note: * indicates presence of co-integrating equations at $5 \%$ level

Source: Author's extraction from Eviews 9 output

The result of the Johansen co-integration shows that there exist at least five co-integrating equations at the 5\% level of significance in both the Trace and Max-Eigen statistics. The trace statistic of the co-integrating equations are higher than the 5\% critical values respectively. An analysis of the first co-integrating equations for both models reveals that $\operatorname{lnCIE}$ and $\operatorname{lnCPS}$ have positive impact on the dependent variables while FDI and UNE are both negative. This is obvious from the computation of t-values. The computation is done by dividing the coefficient by the standard error. By rule of thumb, a t-value greater than 2 shows significance at the $5 \%$ level of significance. This further proves that the null hypothesis of no co-integration is not accepted. Consequent upon this establishment of the presence of co-integration, the ECM specified in equation 3.6 is estimated for the two models. The optimal lag length was determined to be 1 by all the lag length selection criteria

Long Run Regression results

Model 1: Manufacturing model

Table 3: Long run result for model 1

Dependent Variable: LNMAN

Method: Least Squares

\begin{tabular}{|c|r|r|r|r|}
\hline Variable & Coefficient & Std. Error & t-Statistic & Prob. \\
\hline LNCIE & 0.806143 & 0.254247 & 3.170702 & 0.0043 \\
\hline LNCPS & 0.049348 & 0.061497 & 0.802447 & 0.4305 \\
\hline LNFDI & -0.107453 & 0.050052 & -2.146822 & 0.0426 \\
\hline LNGDP & 0.361170 & 0.095302 & 3.789739 & 0.0009 \\
\hline UNE & -0.003215 & 0.007340 & -0.438087 & 0.6654 \\
\hline C & -5.472288 & 1.828644 & -2.992538 & 0.0065 \\
\hline R-squared & 0.957893 & Mean dependent var & 2.866373 \\
\hline Adj R-squared & 0.948739 & S.D. dependent var & 0.666598 \\
\hline F-statistic & 104.6457 & Durbin-Watson stat & 2.051460 \\
\hline Prob(F-statistic) & 0.000000 & \multicolumn{3}{|l}{} \\
\hline Sour:
\end{tabular}

Source: Author's extraction from Eviews 9 output

The result displayed in table 3 above reveals that LNCIE, LNGDP and LNCPS have positive impact on LNMAN. However the impact of LNCPS is not statistically significant at the 5\% level of significance. A $1 \%$ change in electricity supplied for industrial and commercial use increased manufacturing output by about $81 \%$ during the period under review. This was statistically significant at the 5\% level. A $1 \%$ increase in GDP significantly increased manufacturing output by 36\%. The impact of LNFDI is negative and statistically significant, against apriori expectation. This may point to a fact that the manufacturing output in Nigeria is coming more from local investment. A $1 \%$ change in LNFDI decreased manufacturing output by $4.3 \%$. Meanwhile the impact of LNCPS is positive but not significant statistically. A $1 \%$ change in LNCPS increased manufacturing by about $43 \%$. UNE had a negative but not significant impact on LNMAN as expected. A $1 \%$ change in unemployment reduced manufacturing output by 66\%. Nwankwo \& Njogo (2013) found a positive but not significant relationship between expenditures on electricity infrastructure and industrial development. Akinbola et al (2017) and Akiri et al (2015) corroborate the findings of this study of a positive and significant relationship between industrial output and electricity consumption.

The DW statistics of 2.05 (being close to 2) reveals the absence of serial correlation. The explanatory variables used for the model explained about $95.8 \%$ of the variations in the dependent variable. 
Model 2: GDP model

Table 4: Long run regression result for Model 2.

Dependent variable: LNGDP

Method: Least squares

\begin{tabular}{|c|r|r|r|r|}
\hline Variable & Coefficient & Std. Error & t-Statistic & Prob. \\
\hline LNMAN & 1.064327 & 0.280844 & 3.789739 & 0.0009 \\
\hline LNCIE & -0.300623 & 0.519448 & -0.578735 & 0.5684 \\
\hline LNFDI & 0.143267 & 0.089272 & 1.604839 & 0.1222 \\
\hline LNCPS & 0.167148 & 0.101204 & 1.651595 & 0.1122 \\
\hline UNE & -0.004139 & 0.012623 & -0.327918 & 0.7459 \\
\hline C & 2.135517 & 3.673249 & 0.581370 & 0.5666 \\
\hline R-squared & 0.947685 & Mean dependent var & 4.841938 \\
\hline Adj. R-squared & 0.936312 & S.D. dependent var & 1.026617 \\
\hline F-statistic & 83.32854 & Durbin-Watson stat & 2.321774 \\
\hline Prob(F-statistic) & 0.000000 & \multicolumn{3}{|l}{} \\
\hline Source: Author & & & \\
\hline
\end{tabular}

Source: Author's extraction from on Eviews 9

The result displayed in table 4 above reveals that LNMAN, LNFDI and LNCPS have positive impact on LNGDP. However the impact of LNMAN is statistically significant at the $5 \%$ level of significance. A $1 \%$ change in LNMAN increased GDP by $107 \%$. A $1 \%$ change in LNFDI and LNCPS increased GDP by $14.3 \%$ and $16.7 \%$ respectively. LNCIE and UNE both have negative impact on LNGDP and are not statistically significant at the 5\% level. A $1 \%$ change in electricity supplied for industrial and commercial use as well as $1 \%$ change in unemployment reduced GDP by $30 \%$ and $0.4 \%$ respectively.

The finding of this study on electricity supply is corroborated by Adeyemi et al (2016) who found an inverse relationship between electricity consumption and economic growth. However, Adegbemi et al (2016) and Nwankwo \& Njogo (2013) findings fail to agree with this. The DW statistics of 2.33 being close to 2 reveals the absence of serial correlation. The explanatory variables used for the model explained about $94.8 \%$ of the variations in the dependent variable.

\section{Short run regression results}

Model 1: Manufacturing model

\section{Table 5: Short run/ECM results for Model 1}

Dependent variable: D(LNMAN)

Method: Least Squares

\begin{tabular}{|c|r|r|r|r|}
\hline Variable & Coefficient & Std. Error & t-Statistic & Prob. \\
\hline D(LNGDP) & 0.306480 & 0.073171 & 4.188537 & 0.0004 \\
\hline D(LNCIE) & 0.476231 & 0.312519 & 1.523845 & 0.1418 \\
\hline D(LNFDI) & -0.077357 & 0.050402 & -1.534813 & 0.1391 \\
\hline D(LNCPS) & -0.059257 & 0.101950 & -0.581236 & 0.5670 \\
\hline D(UNE) & 0.004155 & 0.008479 & 0.490053 & 0.6289 \\
\hline ECM1(-1) & -0.966012 & 0.202325 & -4.774555 & 0.0001 \\
\hline R-squared & 0.580587 & Mean dependent var & 0.046946 \\
\hline Adj. R-squared & 0.485266 & S.D. dependent var & 0.181607 \\
\hline Durbin-Watson stat & 1.675275 & & & \\
\hline Source: Authors extaction & r & & \\
\end{tabular}

Source: Authors extractions from Eviews 9

From this result, the Error Correction coefficient has the expected negative sign. The system returns to equilibrium after an exogenous shock with a speed of adjustment of $96.6 \%$. This is statistically significant at the $5 \%$ significance level. A $1 \%$ change in GDP is associated with a $30.6 \%$ change in manufacturing output in the short run. This also is significant. In the short run only LNGDP is statistically significant. LNCIE is not significant in explaining manufacturing output in the short run. It however has a positive impact on LNMAN as a $1 \%$ change in LNCIE increased LNMAN by $47.6 \%$ in the short run. 
Model 2: GDP Model

Table 6: Short run/ECM results for Model 2

Dependent variable : D(LNGDP)

Method: Least squares

\begin{tabular}{|c|r|r|r|r|}
\hline Variable & Coefficient & Std. Error & t-Statistic & Prob. \\
\hline D(LNMAN) & 0.788069 & 0.290882 & 2.709238 & 0.0131 \\
\hline D(LNFDI) & 0.065710 & 0.098746 & 0.665442 & 0.5130 \\
\hline D(LNCIE) & 0.015843 & 0.617005 & 0.025677 & 0.9798 \\
\hline D(LNCPS) & 0.422887 & 0.287295 & 1.471961 & 0.1559 \\
\hline D(UNE) & -0.010357 & 0.017284 & -0.599247 & 0.5554 \\
\hline C & -0.048597 & 0.091521 & -0.530991 & 0.6010 \\
\hline ECM2(-1) & -1.139504 & 0.217450 & -5.240314 & 0.0000 \\
\hline R-squared & 0.668397 & Mean dependent var & 0.077957 \\
\hline Adj. R-squared & 0.573654 & S.D. dependent var & 0.380789 \\
\hline F-statistic & 7.054795 & Durbin-Watson stat & 1.938498 \\
\hline Prob(F-statistic) & 0.000324 & \multicolumn{3}{|l}{} \\
\hline Source: Author & \multicolumn{3}{|l}{} \\
\hline
\end{tabular}

Source: Authors extractions from Eviews 9

Table 6 above shows that the Error Correction coefficient has the expected negative sign. The system returns to equilibrium after an exogenous shock with a speed of adjustment of $113.9 \%$ and this is statistically significant at the 5\% significance level. A $1 \%$ change in LNMAN is associated with a $72.8 \%$ change in LNGDP. This is also significant. In the short run only LNMAN is significant. LNCIE has a negative impact on LNGDP; causing an almost equal change in the dependent variable. It is also not statistically significant at the 5\% significance level.

\section{Causality tests}

Granger Causality tests was done in order to know causality and its direction for Nigeria. The results will also help categorize Nigeria correctly under the energy-led growth hypothesis, although this is relevant only for model 2. The full test result is attached in the Appendix F.

\section{Table 7 : Results for Causality Tests}

\begin{tabular}{|c|c|c|c|}
\hline Null Hypothesis & Obs & F-Statistic & Prob. \\
\hline LNMAN does not Granger Cause LNCIE & 28 & 0.97129 & 0.3338 \\
\hline LNCIE does not Granger Cause LNMAN & & 8.71046 & 0.0068 \\
\hline LNGDP does not Granger Cause LNCIE & 28 & 3.13956 & 0.0886 \\
\hline LNCIE does not Granger Cause LNGDP & & 5.67100 & 0.0252 \\
\hline
\end{tabular}

Source: Authors extractions from Eviews 9

From table 7 above, the result for the first pairwise Granger causality revealed that the null hypothesis that LNMAN does not granger cause LNCIE cannot be accepted. However the reverse cannot be rejected. We conclude that there is a unidirectional causality from LNMAN to LNCIE (p-value of the F-statistic being 0.3338). On the second pair of causality test, there is a unidirectional causality between electricity consumption and economic growth; the direction of causality being from LNGDP to LNCIE; revealing a conservation hypothesis of the energy-growth hypothesis. This result is corroborated by Bernard (2014) who also found a unidirectional causality between energy consumption and economic growth in Nigeria. Babatunde \& Adenikinju (2016) reported no causality between energy consumption and economic growth. The findings of this study are also contrary to the report of Apergis \& FoonTang (2013) who opined that Granger causality models with three and four variables are more likely to support the energy-led hypothesis of unidirectional causality from energy to economic growth. The findings of this study support the conservation hypothesis which suggests that economic growth causes an increase in energy consumption.

\section{Test for structural break}

Structural break occur when an event has affected the trend of a series that is when movement is distorted in a series. A plot of the CUSUM of Square for Model 1 as shown in fig 1 revealed there is a deviation from the boundaries at the 2005 point. (the exact year of the unbundling of PHCN) 


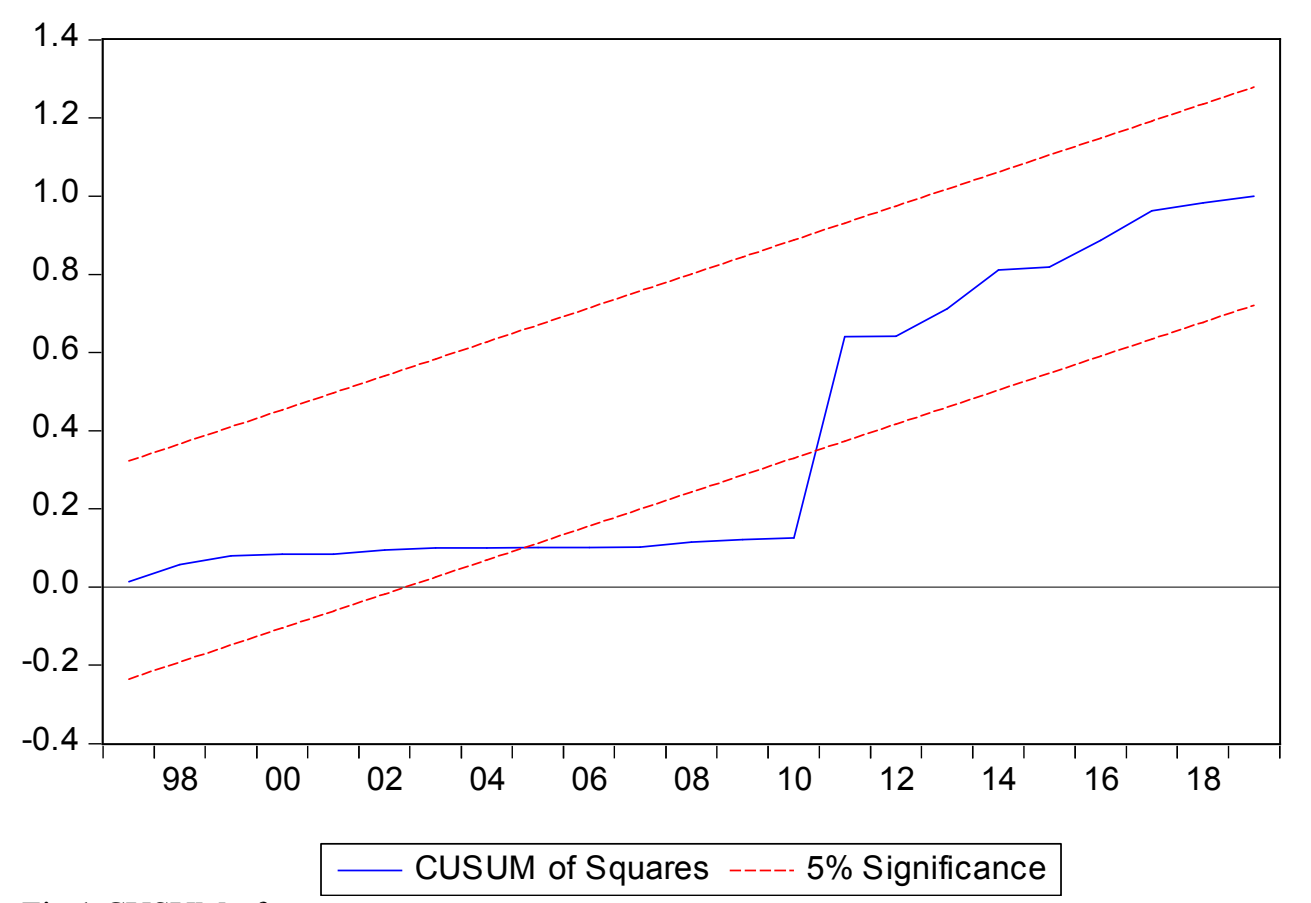

Fig 1 CUSUM of squares

Source: Authors extractions from Eviews 9

A chow test was therefore done at the 2005 point and the result is given below on table 8 . 
Table 8 Chow test for Model 1

Chow Breakpoint Test: 2005

Null Hypothesis: No breaks at specified breakpoints

Varying regressors: All equation variables

Equation Sample: 19912019

\begin{tabular}{llll}
\hline \hline F-statistic & 1.887363 & Prob. F(6,17) & 0.1416 \\
Log likelihood ratio & 14.80457 & Prob. Chi-Square(6) & 0.0218 \\
Wald Statistic & 11.32418 & Prob. Chi-Square(6) & 0.0789 \\
\hline
\end{tabular}

Source: Authors extractions from Eviews 9

The null hypothesis of the chow test says there are no breaks at the specified breakpoints (2005). The prob value of the F-stat is not statistically significant; we therefore accept the null and conclude that the structural break is not significant.

The CUSUM of squares for model 2 is also presented in Fig 2 below.

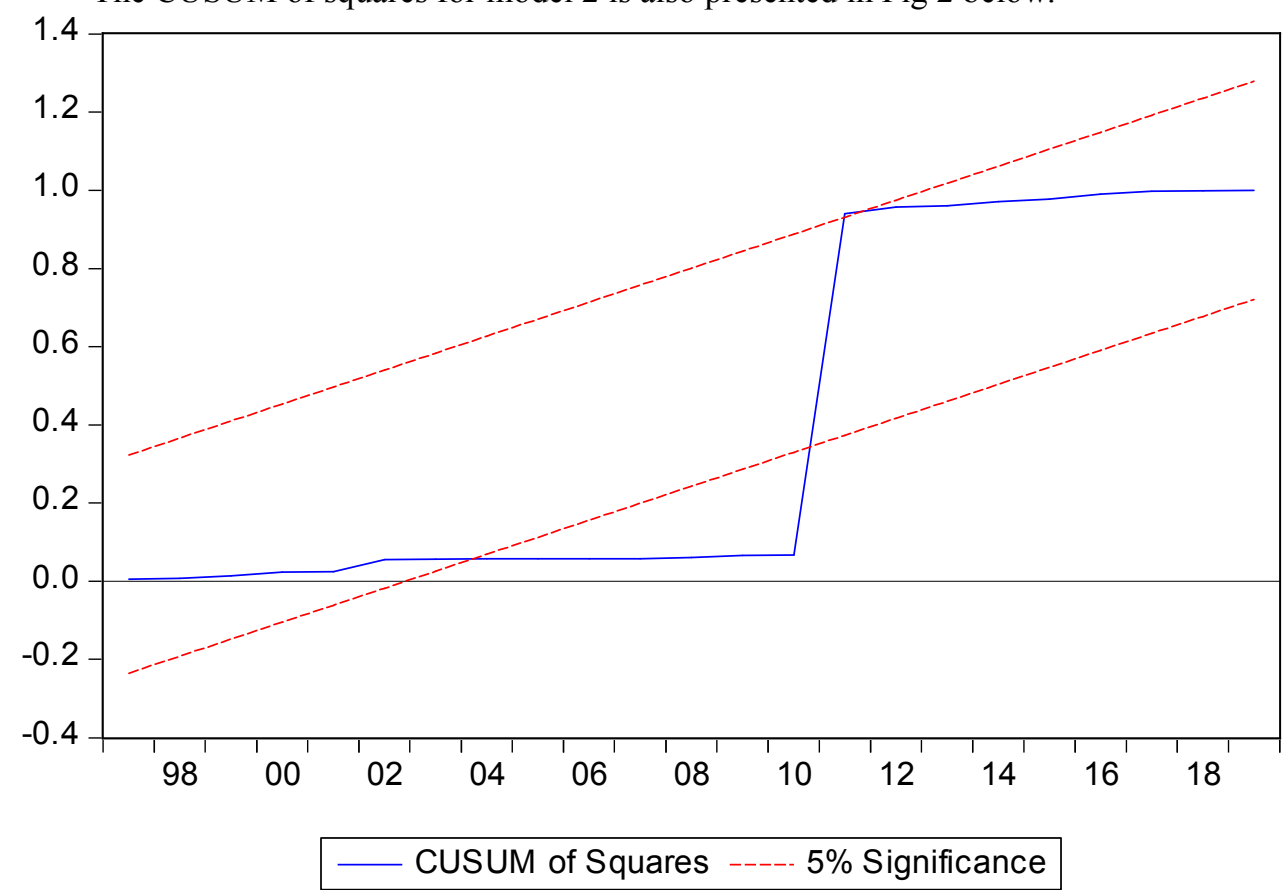

Fig 2 CUSUM of squares for model 2

Source: Authors extractions from Eviews 9

Again a Chow test was done to assess the statistical significance of the break shown in Fig 2 above. Result is shown in Table 9.

Table 9 Chow test for Model 2

Chow Breakpoint Test: 2003

Null Hypothesis: No breaks at specified breakpoints

Varying regressors: All equation variables

Equation Sample: 19912018

\begin{tabular}{llll}
\hline \hline F-statistic & 1.395563 & Prob. F(6,16) & 0.2758 \\
Log likelihood ratio & 11.78528 & Prob. Chi-Square(6) & 0.0669 \\
Wald Statistic & 8.373377 & Prob. Chi-Square(6) & 0.2120 \\
\hline \hline
\end{tabular}

Source: Authors extractions from Eviews 9

The null hypothesis of the chow test says there are no breaks at the specified breakpoints (2003). The prob value of the F-stat is not statistically significant; we therefore accept the null and conclude that the structural break is not significant.

\section{CONCLUSION AND RECOMMENDATION}

The study examined the relationship between manufacturing output, economic growth and electricity consumption in Nigeria over the period 1991 to 2019. The study revealed positive relationship between manufacturing output 
and electricity consumption. It also revealed a positive relationship between economic growth and electricity consumption with a unidirectional causality from economic growth to electricity consumption. Following this, the study concluded that there is a significant relationship between manufacturing and electricity consumption while the relationship between economic growth and electricity consumption is not statistically significant.

Based on the findings and conclusion, the following recommendations are made:

a. There is urgent need to prepare the ground for huge availability of electricity supply by developing all needed infrastructure for adequate production because as the economy grows there will be an increased demand for electricity supply especially for industrial and commercial use

b. Electricity supply for industrial and commercial use needs to be stepped up as this will boost production while reducing expenditure and in the long run improve employment opportunities and economic growth.

\section{References}

Adegbemi, B.O.; Adegbemi, O.O; Olalekan, A.J. \& Babatunde, O.O. (2013). Energy consumption and Nigerian economic growth: An empirical analysis. European Scientific Journal. 9(4):25-40.

Adeyemi, A.O.; Opeyemi, A. \& Oluwatomisin, M.O. (2016). Electricity consumption and economic development in Nigeria. International Journal of Energy Economics and Policy. 6(1): $134-143$.

Ahmed, A. \& Mallo, M.J. (2015). Impact of deficient electricity supply on the operations of small scale businesses in North East Nigeria. International Journal of Business and Economic Development. 3(1);20-30.

Akinbola, O.A.; Zekeri, A. \& Idowu, H.A.O. (2017). The power sector and its impact on industrialization of businesses in Nigeria. Achieves of Business Research. 5(11): $294-305$.

Akinlo, A.E. (2009). Electricity consumption and economic growth in Nigeria: evidence from cointegration and co-feature analysis. Journal of Policy Modelling. 31(5): 681 - 693.

Akiri, S.E.; Ijuo. O.A. \& Apochi, M.P (2015). Electricity supply and the manufacturing productivity in Nigeria (1980 - 2012). Journal of Economics and Finance. 6(6);90-94.

Apergis, N \& FoonTang, C. (2013). Is the energy-led growth hypothesis valid? New evidence from a sample of 85 countries. Retrieved online at http:doi.orh.10.1016/j.eneco.2013:02.007 on $13^{\text {th }}$ October, 2020.

Apergis, N. \& Danuletiu, D. (2012). Energy Consumption and Growth in Romania: Evidence from a Panel Error Correction Model. International Journal of Energy Economics and Policy. 2(4): 348 - 356.

Awosepe, C.A. (2014). Nigeria electricity industry: Issues, challenges nd solutions. Covenant University $38^{\text {th }}$ Public Lecture Series. 3(2).

Babatunde, M.A. \& Adenikinju, A. (2016). Energy consumption and economic growth in Nigeria: a time -varying framework analysis. Retrieved online at researchgate.net/publication $/ 324759970_{-}$energy consumption and economic growth on $23^{\text {rd }}$ October, 2020.

Behera, J. (2015). The energy-led growth hypothesis in India: evidence from time series analysis. Energy Economics Letters. DOI: 10.18488/journal.82/2015.2.4/82.4.46.65.

Bernard, N.I. (2014). Electricity consumption, inflation and economic growth in Nigeria: a dynamic causality test. Retrieved online at https://mpra.ub.uni-muenchen.de/68514/ on $21^{\text {st }}$ July, 2020.

Bureau of public enterprises, BPE (1999). History of privatization. Retrieved online at bpe.gov.ng/about/history/ on $13^{\text {th }}$ October, 2020.

Ehimhen, K.M. (2015). The state of Nigerian power sector and its economic implications for the nation. Stelmatson Global Publications. Retrieved online at orcid.org/0000-0003-4629-7789 on 20th July 2020.

George-Anokwuru, C.C \& Ekpeyong, B.I. (2020). Electricity and economic growth in Nigeria. Journal of Economics, Business and Market Research. 1(1): 1 - 7.

Liberto, D. \& Esteveze, E. (2020). Endogenous growth theory definition. Retrieved online at investopedia.com/terms/e/endogenousgrowththeorydefinition.asp on $25^{\text {th }} \mathrm{July,} 2021$.

Muhammad, S.G.G. (2015). Privatization and commercialization in Nigeria. Retrieved online at academia.edu/12481441/privatization_and_commercialization_in_Nigeria on $14^{\text {th }}$ October, 2020.

Nnanna, I. and Uzorh, A.C. (2011) The impact of power outage on Nigeria manufacturing sector. NIIE Proceedings, Ibadan, 4-6 August 2011, 45-56.

Nnoli, K.P.; Bolu, J.I. \& Obazenu, J.O. (2016). Deregulation of electric power in a developing economy: prospects for Nigeria. International Research Journal of Engineering and Technology. Retrieved online at www.irjet.net On $21^{\text {st }}$ July, 2020.

Nwankwo, O.C. \& Njogo, B.O. (2013). The effect of electricity supply on industrial production within the Nigerian economy (1970 - 2010). Journal of Energy Technologies and Policy. 3(4): 34 - 47.

Okolobah, V. \& Ismail, Z. (2013). On the issues, challenges and prospects of electrical power sector in Nigeria. International Journal of Economy, Management and Social Sciences. 2(6) : 410 - 418.

Okorie, D.I. \& Manu, S.A. (2016). Electricity consumption and economic growth: The Nigerian case. International Journal of Current Research. 8(12): 8 - 17.

Phung, T.B. (2011). Energy Consumption and Economic Growth in Vietnam: Threshold co-integration and 
Causality Analysis. International Journal of Energy Economics and Policy. 1(1): 1- 17.

Romer, P.M. (1994). The origins of endogenous growth. Retrieved online at pubs.aeaweb.org/doi/pdt/10.1257/jep.8.1.3 on $4^{\text {th }}$ Novmber, 2020.

Ubi, P.S; Effiom, L.; Oon, E.O. \& Oduneka, A.E. (2012). An econometric analysis of the determinants of electricity supply in Nigeria. International Journal of Business Administration. 3(4) : $72-82$.

Ukoima, K.N. \& Ekwe, O.A. (2019). Review of the impact of electricity supply on economic growth: A Nigerian case study. IOSR Journal of Electrical and Electronics Engineering. 14(1) ; 28 - 34. 